\title{
Role of the Rutin and Genistein Flavonoids in Soybean Resistance to Piezodorus guildinii (Hemiptera: Pentatomidae)
}

\author{
José P. F. Bentivenha ${ }^{1}$ - Vinícius F. Canassa ${ }^{2}$. Edson L. L. Baldin ${ }^{2} \cdot$ Milena G. Borguini $^{3}$ - Giuseppina P. P. Lima ${ }^{3}$. \\ André L. Lourenção ${ }^{4}$
}

Received: 15 November 2016 / Accepted: 21 October 2017 / Published online: 20 November 2017

() Springer Science+Business Media B.V. 2017

\begin{abstract}
The stink bug complex includes some of the most important soybean pests worldwide. Among these insects, Piezodorus guildinii (Westwood) (Hemiptera: Pentatomidae) is known for the severe damage it can cause and for its resistance to chemical management. Host plant resistance is considered as an important tool in the management of these pests. In particular, plant flavonoids, such as genistein and rutin, have been identified as compounds that might negatively affect the development of some pests; however, the effects of these compounds on some stink bug species are still unclear. We tested the resistance of soybean genotypes by evaluating the growth and survival of $P$. guildinii under laboratory conditions. In addition, the amounts of genistein and rutin were quantified in both infested and non-infested genotypes. The PI 274453, PI 274454, PI 227687, PI 229358, 'IAC 100', and 'IAC 19' genotypes showed antibiosis to P. guildinii. The genistein and rutin flavonoids appear to play a role in the resistance of these genotypes against $P$. guildinii; specifically, PI 274453, PI 274454, and 'IAC 100' showed induced resistance against the insect. Other defence mechanisms or flavonoids might be involved in resistance in the L1-1-01 and PI 171451 genotypes. These results help us better understand the role of flavonoids in plant defence mechanisms and might prove useful in breeding programmes aimed at developing resistant soybean plants.
\end{abstract}

Keywords Glycine max $\cdot$ Induced resistance $\cdot$ Flavonoid $\cdot$ Redbanded stink bug $\cdot$ Antibiosis

\section{Introduction}

The redbanded stink bug Piezodorus guildinii (Westwood) (Hemiptera: Pentatomidae) is one of the most important pests of soybean, Glycine max (L.) Merrill (Panizzi and Slansky 1985). Soybean is the main legume crop grown in

Communicated by Rupesh Kariyat.

José P. F. Bentivenha

jpbentivenha@gmail.com

1 Department of Entomology and Acarology—Luiz de Queiroz College of Agriculture, University of Sao Paulo, Piracicaba, Sao Paulo 13418-900, Brazil

2 Department of Crop Protection-College of Agronomic Sciences, Sao Paulo State University, Botucatu, Sao Paulo 18610-307, Brazil

3 Department of Horticulture-College of Agronomic Sciences, Sao Paulo State University, Botucatu, Sao Paulo 18610-307, Brazil

4 Phytosanitary Center, Agronomic Institute of Campinas, Campinas, Sao Paulo 13012-970, Brazil
South and North America (Zavala et al. 2015). In South America's Southern Cone (spanning Uruguay and Argentina), this stink bug species causes the largest economic loss to soybean (Zerbino 2010). In Brazil, the species has been identified as one of the major species in the stink bug complex (Souza et al. 2015). P. guildinii has also been reported in the United States since the early 1900s throughout the states of South Carolina, Florida, Georgia, and New Mexico (McPherson and McPherson 2000), although it had not been considered as a major soybean pest (Panizzi and Slansky 1985; McPherson et al. 1993). Nevertheless, in the last decade, $P$. guildinii was the dominant species of the stink bug complex, covering more than $50 \%$ of the stink bugs collected in the southern United States (Kamminga et al. 2012, Temple et al. 2013).

Stink bugs cause damage to soybean by inserting their stylets into the seeds and injecting salivary secretions to facilitate ingestion, which causes seed abortion or deformation, decreased germination, and, consequently, a decrease in yield (Todd and Turnipseed 1974). The damage caused by stink bugs such as $P$. guildinii may also 
be related to leaf retention, a physiological condition that delays the maturation of soybean plants through the maintenance of green leaves after pod maturation (Sosa-Gómez and Moscardi 1995; Corrêa-Ferreira and Azevedo 2002).

The management of stink bug populations is difficult due to the limited number of available insecticides and rapid evolution of insecticide resistance, which often results in an increased number of insecticide applications and the use of broad-spectrum products (Baur et al. 2010). In this context, host plant resistance, as part of an integrated pest management strategy, is an appropriate tactic for crop protection, as it significantly reduces the problem of insecticide resistance (Painter 1951; Smith 2005).

The resistance of a plant to an insect is typically described in three ways: antibiosis, antixenosis, and tolerance. In the case of antibiosis, the plant is deleterious to the arthropod, affecting its biology, although the arthropod can use the plant normally as its host. In the case of antixenosis, the presence of a biochemical, physical, or biological factor in the plant negatively affects pest behaviour (e.g. colonization, oviposition, and feeding). Finally, tolerant plants have the ability to resist or recover from an arthropod attack without affecting the arthropod's behaviour or biology (Smith and Clement 2012).

Plants might respond to insect attacks by up-regulating defence compounds that can deter or ameliorate the injuries caused by arthropods (Underwood et al. 2002; Zavala et al. 2008, 2009). Flavonoids are chemical substances generated by soybean plants that can negatively affect insect attacks. The composition and concentration of these substances in plants depend on both environmental and genetic factors (Carrão-Panizzi and Kitamura 1995). For instance, UV-B radiation is an environmental factor that can induce flavonoid accumulation in the leaves of common bean (Phaseolus vulgaris) (Beggs and Wellman 1994), and flavonoid accumulation has been shown to decrease attacks by caterpillars such as Anticarsia gemmatalis (Hübner) and Caliothrips phaseoli (Hood) in soybean (Mazza et al. 1999; Zavala et al. 2001).

One such flavonoid is genistein, and results have shown that this compound can have negative effects on the behaviour and biology of A. gemmatalis and Trichoplusia ni (Hübner) larvae (Hoffmann-Campo et al. 2001). Studies involving the green stink bug Nezara viridula (L.) have shown that attack by this bug induces increased levels of the isoflavone glycosides daidzein and genistein in soybean seeds. The same study reported that this species prefers to feed on seeds that display low levels of flavonoids (Piubelli et al. 2003a, b). Another flavonoid reported to be involved in antibiosis observed in soybean genotypes is rutin, which affected some biological parameters of $T$. $n i$ (Hoffmann-Campo et al. 2001) and A. gemmatalis (Piubelli et al. 2005).
Although previous studies have reported the existence of soybean genotypes that express resistance to stink bugs, e.g. $N$. viridula (McPherson et al. 2007), few have focused on $P$. guildinii, (Silva et al. 2013, 2014). Even fewer studies have attempted to describe the mechanisms involved in soybean resistance to stink bugs, such as the presence and induction of flavonoids (McPherson and Buss 2007; McPherson et al. 2007; Lourenção et al. 2010; Silva et al. 2014).

Considering the importance of soybean worldwide and the increasing occurrence of $P$. guildinii, this study evaluated the effects of soybean genotypes on $P$. guildinii fitness, under laboratory conditions. In addition, due to the previous observed effects of genistein and rutin, and the necessity to better understand the role of these flavonoids in the resistance of soybean genotypes against $P$. guildinii, the concentrations of constitutive and stink bug-induced flavonoids in different genotypes were estimated.

\section{Materials and methods}

\section{Rearing of Piezodorus guildinii stock}

A population of $P$. guildinii was maintained under controlled conditions (14:10 h L:D at $26 \pm 2{ }^{\circ} \mathrm{C}$ and $\left.65 \pm 10 \% \mathrm{RH}\right)$ as described in (Silva et al. 2013). To avoid a pre-preference of P. guildinii for certain host plants (Smith 2005), egg masses, nymphs, and adults were collected from various cultivated soybean genotypes near Botucatu, SP, Brazil (22 $88^{\prime} 42^{\prime \prime}$ S; $48^{\circ} 44^{\prime} 42^{\prime \prime} \mathrm{W}$ ), all of which differed from the genotypes used in this study.

The adults were maintained in plastic containers $(8 \mathrm{~L}$, $22 \mathrm{~cm}$ diameter and $20 \mathrm{~cm}$ in height) covered with organdy ("voil") to allow adequate ventilation. The bottom surfaces of the containers were lined with filter paper to absorb excrement and maintain sanitary conditions. Each container housed 25 couples, which were maintained on a natural diet of green pods [P. vulgaris (L.)] (5 pods/container) and raw peanuts [Arachis hypogaea (L.)] in portions of $50 \mathrm{~g} /$ cage, which were deposited in Petri dishes. The food was replaced and the containers cleaned every 4 days to avoid fungal contamination. Cotton moistened with distilled water was placed in the Petri dishes to meet the hydration needs of the bugs and to maintain moisture levels within the containers. Discs of dry cotton were placed equidistantly along the bottom surface of the container to serve as oviposition sites and shelter for the insects. The discs were suspended along the top edge of the cage using hooks fashioned from number two paper clips. To ensure that the eggs were not consumed by the adults (Panizzi 1991); the eggs were collected daily and placed in Petri dishes ( $8.5 \mathrm{~cm}$ diameter) lined with moistened filter paper and containing a bean pod to serve as a food source for the insects in the first nymphal stage. 
When the insects reached the second nymphal stage, they were transferred to plastic containers prepared as described previously.

\section{Antibiosis assay}

The origins/pedigrees and resistance characteristics of the ten genotypes utilized in this study are described in Table 1 . The pods utilized in the antibiosis tests were collected from infested plants. These plants were sown in pots containing $5 \mathrm{~L}$ of sterilized and fertilized soil (Raij et al. 1997). Each pot contained two soybean plants, for a total of ten pots per genotype, and were maintained in a greenhouse. When the plants reached the R5/R6 stage (Fehr and Caviness 1977), they were placed under metal frame cages $(40 \mathrm{~cm}$ in diameter $\times 60 \mathrm{~cm}$ in height) lined with an organdy fabric. Two males and two females of $P$. guildinii ( $24 \mathrm{~h}$ of age) were released into these cages and were replaced every seven days to maintain the vigour of the insect infestation.

The biological performance of $P$. guildinii on the soybean genotypes was evaluated in the laboratory $\left(\mathrm{T}=26 \pm 2{ }^{\circ} \mathrm{C}\right.$, $\mathrm{RH}=65 \pm 10 \%$, photoperiod $=14 \mathrm{~h}$ ), following methodology previously described in literature, using uninfested soybean pods (undamaged plants) (Silva et al. 2013). The following parameters were evaluated: duration of nymphal stages (N2-N5), developmental period (egg-adult), mortality in each nymphal instar, and mortality in the nymphal stage.

Egg masses (up to $24 \mathrm{~h}$ old) from the reared stock were placed in Petri dishes ( $3 \mathrm{~cm}$ diameter) lined with moistened filter paper and containing a pod from one of the soybean genotypes of interest. After hatching, the nymphs were left undisturbed until they reached the second nymphal stage. Then, five insects (first day of the second-instar stage) were transferred to Petri dishes $(8.5 \mathrm{~cm}$ in diameter and $1.5 \mathrm{~cm}$ in height) lined with filter paper and containing a piece of moistened cotton. These dishes contained two soybean pods from one of the infested genotypes plants in the R5/ R6 phase, which allowed monitoring of $P$. guildinii biology in association with different soybean genotypes. First-instar nymphs were not used in the bioassay due to the fragility of these insects and the gregarious behaviour they often display due to various olfactory stimuli (Lockwood and Story 1986). Moreover, first-instar nymphs do not feed (Panizzi 1991).

The insects were assessed daily at the same time of the day until the end of the nymphal stage. The dead insects were recorded for the calculation of mortality and viability. After emergence, the insects were maintained under the same conditions to assess their longevity across plant genotypes. For those insects that survived to adulthood, adult insect weight was individually determined after $24 \mathrm{~h}$ using a Mars AY 220 analytical balance $(0.0001 \mathrm{~g})$. Exuviae and dead insects were removed daily at the time of the evaluations using a metal clamp with the tip wrapped in cotton cloth. Each Petri dish containing five insects constituted a replicate, with 10 replicates per genotype arranged in a completely randomized design.

\section{Flavonoid assay}

To produce soybean pods for the flavonoid bioassay, ten plants of each genotype were grown using the same methodology described previously. When the plants reached the R5/ R6 stage (Fehr and Caviness 1977), five were placed under metal-framed cages $(40 \mathrm{~cm}$ in diameter $\times 60 \mathrm{~cm}$ in height) lined with organdy fabric. Two males and two females of $P$. guildinii ( $24 \mathrm{~h}$ of age) were released into the cages. After two days, 10 pods from the lower third of the plants (two pods per plant) were collected for the flavonoid bioassay. The other five plants of each genotype were not infested by insects (undamaged pods) and were used as controls. The

Table 1 Soybean genotypes assessed for resistance to the stink bug complex and other arthropods

\begin{tabular}{|c|c|c|}
\hline Genotype & Pedigree/Origin & Resistance characteristics \\
\hline PI 171451 & Japan & Antixenosis/antibiosis vs. $P$. guildinii; resistance vs. Lepidoptera \\
\hline PI 229358 & Tokyo, Japan & Antixenosis/antibiosis vs. $P$. guildinii; resistance vs. Lepidoptera \\
\hline PI 227687 & Okinawa, Japan & Antixenosis/antibiosis vs. $P$. guildinii; resistance vs. Lepidoptera \\
\hline PI 274453 & Okinawa, Japan & Antixenosis/antibiosis vs. $P$. guildinii; resistance vs. Lepidoptera \\
\hline PI 274454 & Okinawa, Japan & Antixenosis/antibiosis vs. $P$. guildinii; resistance vs. Lepidoptera \\
\hline L1-1-01 & BR-6 × 'IAC 100’ & Antibiosis vs. $P$. guildinii \\
\hline 'IAC 19’ & D 72-9601-1 × 'IAC 8' & Antixenosis/antibiosis vs. $P$. guildinii; antibiosis/antixenosis vs. $B$. tabaci \\
\hline 'IAC 100' & 'IAC 12 ' $\times$ IAC 78-2318 & $\begin{array}{l}\text { Antixenosis/antibiosis vs. } P \text {. guildinii; antixenosis vs. E. heros; resistance } \\
\text { vs. Lepidoptera defoliation; resistance vs. } N \text {. viridula. }\end{array}$ \\
\hline 'Coodetec 208' & OC-4 $\times$ Williams 20 & - \\
\hline 'Conquista' & Lo76-44842 × Numbaíra & antibiosis/antixenosis vs. $B$. tabaci \\
\hline
\end{tabular}

Source: (Miranda et al. 1979; Lourenção and Miranda 1987; Valle and Lourenção 2002; Hulburt et al. 2004; McPherson and Buss, 2007; McPherson et al. 2007; Hesler and Dashiell 2008; Lourenção et al. 2010; Silva et al. 2012, 2013, 2014; Souza et al. 2015) 
collected pods were employed to determine the flavonoid concentration in each treatment.

Flavonoid determination was conducted according to an adapted spectrophotometric method (Santos and Blatt 1998; Awad et al. 2000). The extraction protocol was adapted in the following way. Samples were homogenized in $70 \%$ of methanol, acidified with $10 \%$ of acetic acid (v/v), and conducted to ultrasonic bath (Awad et al. 2000). The samples were centrifuged at $10000 \mathrm{rpm}$; the supernatant was isolated, and the precipitant was extracted in the same methanol: acetic acid solution. After a new centrifugation, the supernatant was mixed. In aliquots of theses mixed it was added $5 \%$ of aluminium chloride. After $30 \mathrm{~min}$, the measurement were performed in spectrophotometric readings, at $425 \mathrm{~nm}$, and the results were expressed in $\mu \mathrm{g}$ of the flavonoids genistein and rutin $\mathrm{g}^{-1}$ of equivalent fresh mass. These flavonoids were chosen due to the previous studies which demonstrated their influences on the biology of lepidopterans and $N$. viridula (Hoffmann-Campo et al. 2001; Piubelli et al. 2003a, b). It is important to note that the level of induced resistance expression is coordinated by both abiotic (soil, temperature, humidity) and biotic (including plant and insect characteristics) factors (Smith 2005). Thus, in this study, the use of pods from the lower third of the plants was standardized. All of the plants were subjected to similar conditions, and healthy, viable insects were used. Therefore, the data collected in this study represent the variation in constitutive and induced flavonoids linked to genotypic differences and no other environmental factors.

\section{Statistical analysis}

Antibiosis assay data were tested by analysis of variance and $\mathrm{F}$ test. The distribution of residuals was checked for normality using the Shapiro-Wilk test, and for homogeneity using the Levene test (both considering alpha $=0.05$ ). Fisher's LSD test $(\mathrm{P}<0.05)$ was performed to compare the means of the genotypes. Statistical analysis was performed using the PROC GLM procedure in the SAS software package (SAS Institute 2001). The flavonoid data were also analysed with ANOVA (SAS Institute 2001) using a factorial arrangement (10 by 2 ), where 10 represents the number of genotypes and 2 represents the infested and non-infested plants. Fisher's LSD test $(\mathrm{P}<0.05)$ was performed to compare the means in flavonoid concentration for the genotypes.

\section{Results}

\section{Antibiosis assays}

A mortality rate greater than $75 \%$ was observed for secondinstar nymphs reared on the 'IAC 19', PI 274454, PI 274453,
PI 229358, and PI 171451 genotypes (Fig. 1). Insects reared on the L1-1-01 genotype showed a lower second-instar mortality rate (52\%); third- and fourth-instar nymphs also showed significant mortality rates $(22 \%$ and $20 \%$, respectively) when reared on this genotype. Insects reared on the 'IAC 100' genotype showed a second-instar mortality rate of just $38 \%$ and third- and fifth-instar mortality rates of $36 \%$ and $24 \%$, respectively. Most of the nymphal mortality observed for insects reared on the 'Conquista' and 'Coodetec 208' genotypes occurred in the third- and fifth-instars ( $12 \%$ in each instar), with a maximum of $6 \%$ of the nymphs dying during the second-instar. No differences were found among the genotypes for the longevity of adults and adult mass $(F=0.63 ; \mathrm{df}=3,17 ; P=0.6991 ; F=0.83 ; \mathrm{df}=3$, $17 ; P=0.5593)$.

Adult emergence did not occur on genotypes 'IAC 19', PI 274453, PI 274454, 'IAC 100', PI 229358, and L1-1-01 (Fig. 1). On PI 227687 and PI 171451, only 2 and $6 \%$ of the insects became adults, respectively. In contrast, more than $60 \%$ adult emergence occurred on 'Coodetec 208' and 'Conquista' $(F=32.76 ; \mathrm{df}=9,90 ; P<0.0001)$. Nymphal mortality in each instar was high on most of the genotypes (Fig. 1), mainly during the first nymphal instar.

The genotype 'IAC 100' significantly prolonged the duration of the second nymphal instar to 5.7 days compared with PI 229358, L1-1-01, PI 171451, 'Conquista', and 'Coodetec 208 ' (less than 4.9 days) $(F=5.47 ; \mathrm{df}=9,47 ; P<0.0001)$ (Table 2). In the third-instar, nymphs took more time to develop on PI 171451 (6.0 days) and 'IAC 100' (5.1 days) compared with 'Conquista', 'Coodetec 208', and PI 229358 $(F=5.41 ; \mathrm{df}=6,35 ; P<0.0005)$, which allowed fast development (equal to or less than 4.2 days) of $P$. guildinii. Regarding the fourth-instar, L1-1-01 differed ( $F=5.69$; $\mathrm{df}=6,22 ; P<0.0011)$ from the majority of genotypes in prolonging development to 7.7 days. There was no difference in the fifth-instar, where the duration varied from 6.0 days in PI 171451 to 7.2 days in 'Conquista' $(F=0.53$; $\mathrm{df}=3,16 ; P=0.6671)$. Similarly, no difference occurred in the total duration of the cycle (1st-5th instars), with the insects presenting a nymphal duration between 19.0 days on PI 227687 and 17.8 days on 'Conquista' $(F=0.10 ; \mathrm{df}=3$, $17 ; P=0.9596)$.

\section{Flavonoid assays}

Among the control (non-infested) plants (Fig. 2), the highest genistein concentrations were observed $(>4.19 \mathrm{~g} / 100 \mathrm{~g})$ in the 'IAC 19', PI 229358, and PI 227687 genotypes $(F=190.50 ; \mathrm{df}=19 ; P<0.0001)$. The lowest concentrations $(\leq 2.30 \mathrm{~g} / 100 \mathrm{~g})$ were observed in the 'Conquista', L1-1-01, and PI 171451 genotypes. Among the infested plants, the highest genistein concentration values in the PI 274453, PI 274454, PI 227687, and 'IAC 19' genotypes, 

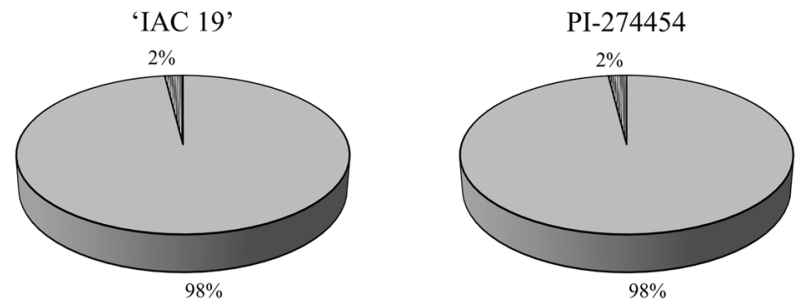

'IAC 100'

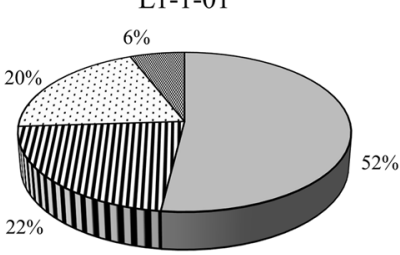

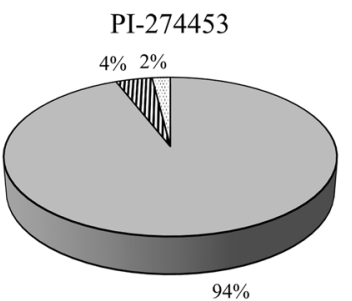

PI-227687

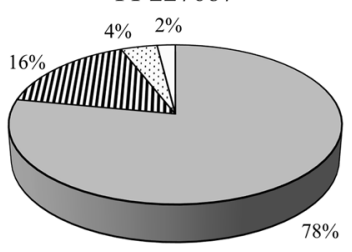

'Coodetec 208'
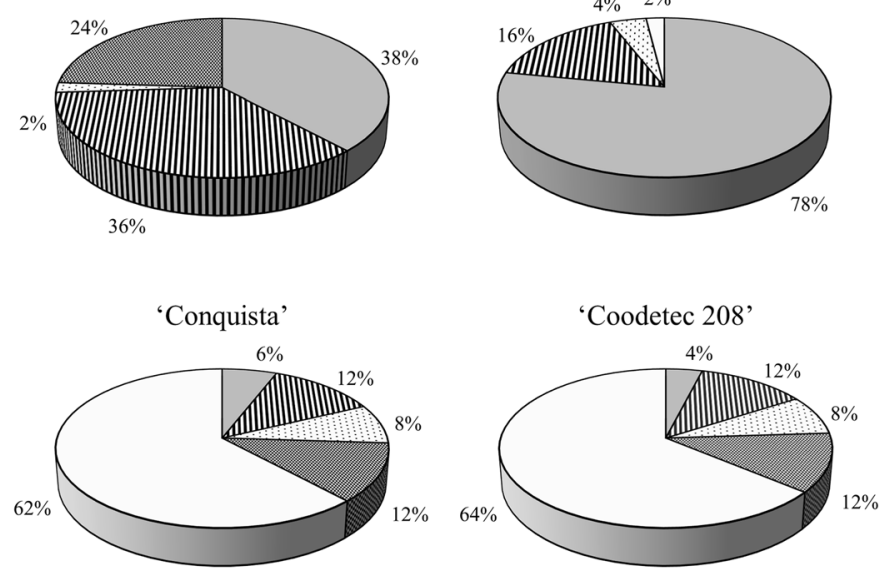

PI-229358

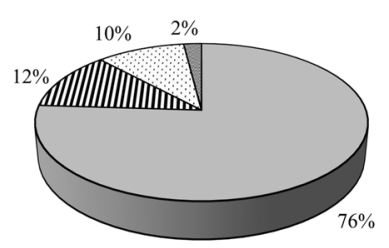

PI-171451

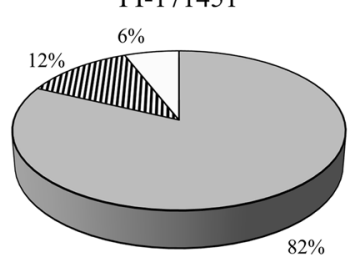

Fig. 1 Percentages of mortality in 2nd to 5th nymphal instars and adult emergence of Piezodorus guildinii on ten soybean genotypes $\left(\mathrm{T}=26 \pm 2{ }^{\circ} \mathrm{C}, \mathrm{RH}=65 \pm 10 \%\right.$, and photoperiod $\left.=14 \mathrm{~h}\right)$

Table 2 Mean $( \pm \mathrm{SE})$ duration of each instar and the total development of Piezodorus guildinii on ten soybean genotypes $\left(\mathrm{T}=26 \pm 2{ }^{\circ} \mathrm{C}\right.$, $\mathrm{RH}=65 \pm 10 \%$, and photoperiod $=14 \mathrm{~h}$ )

\begin{tabular}{|c|c|c|c|c|c|}
\hline \multirow[t]{2}{*}{ Genotype } & \multicolumn{5}{|c|}{ Developmental time (days) ${ }^{\mathrm{a}}$} \\
\hline & 2nd instar & 3rd instar & 4th instar & 5 th instar & Cycle $^{\mathrm{b}}$ (1st -5 th instar $)$ \\
\hline 'IAC 100’ & $5.7 \pm 0.29(\mathrm{n}=24)^{\mathrm{c}} \mathrm{a}$ & $5.1 \pm 0.32(\mathrm{n}=2) \mathrm{ab}$ & $5.9 \pm 0.58(n=2) b$ & $-{ }^{\mathrm{d}}$ & $-^{\mathrm{d}}$ \\
\hline PI-274453 & $5.0 \pm 0.82(\mathrm{n}=3)^{\mathrm{e}} \mathrm{ab}$ & $-{ }^{\mathrm{d}}$ & $-{ }^{\mathrm{d}}$ & $-^{\mathrm{d}}$ & $-{ }^{\mathrm{d}}$ \\
\hline PI-274454 & $5.0 \pm 0.82(\mathrm{n}=1) \mathrm{ab}$ & $-{ }^{\mathrm{d}}$ & $-{ }^{\mathrm{d}}$ & $-{ }^{\mathrm{d}}$ & $-^{\mathrm{d}}$ \\
\hline 'IAC 19' & $5.0 \pm 0.82(\mathrm{n}=1) \mathrm{ab}$ & $-{ }^{\mathrm{d}}$ & $-{ }^{\mathrm{d}}$ & $-^{\mathrm{d}}$ & $-{ }^{\mathrm{d}}$ \\
\hline PI-227687 & $4.9 \pm 0.33(\mathrm{n}=11) \mathrm{ab}$ & $4.3 \pm 0.37(n=3) b c d$ & $4.0 \pm 1.17(\mathrm{n}=1) b$ & $7.0 \pm 0.91(\mathrm{n}=1)$ & $19.0 \pm 2.89(\mathrm{n}=1)$ \\
\hline PI-229358 & $4.6 \pm 0.36(n=12) b$ & $4.2 \pm 0.29(\mathrm{n}=6) \mathrm{cd}$ & $6.0 \pm 1.17(\mathrm{n}=1) a b$ & $-{ }^{\mathrm{d}}$ & $-{ }^{\mathrm{d}}$ \\
\hline L1-1-01 & $4.5 \pm 0.25(\mathrm{n}=24) b$ & $4.5 \pm 0.21(n=15) b c$ & $7.7 \pm 0.58(n=3) a$ & $-{ }^{\mathrm{d}}$ & $-{ }^{\mathrm{d}}$ \\
\hline PI-171451 & $4.4 \pm 0.36(n=9) b$ & $6.0 \pm 0.64(\mathrm{n}=4) \mathrm{a}$ & $3.0 \pm 1.17(n=4) b$ & $6.0 \pm 0.91(n=4)$ & $18.0 \pm 2.89(\mathrm{n}=4)$ \\
\hline 'Conquista' & $3.7 \pm 0.25(n=47) b$ & $3.7 \pm 0.20(n=43) d$ & $4.3 \pm 0.39(n=38) b$ & $7.2 \pm 0.30(\mathrm{n}=32)$ & $17.8 \pm 0.91(n=32)$ \\
\hline 'Coodetec 208' & $3.5 \pm 0.25(n=48) b$ & $3.6 \pm 0.20(n=42) d$ & $4.3 \pm 0.39(n=38) b$ & $7.1 \pm 0.30(\mathrm{n}=32)$ & $18.4 \pm 0.96(n=32)$ \\
\hline$P$ & $<0.0001$ & 0.0005 & 0.0011 & 0.6671 & 0.9596 \\
\hline
\end{tabular}

${ }^{a}$ Means followed by the same letter in each column do not differ by the LSD test $(P>0.05)$

${ }^{\mathrm{b}}$ Duration from first to fifth-instar

${ }^{\mathrm{c}}$ Number of insects evaluated

${ }^{\mathrm{d}}$ No insects reached this instar or completed the cycle

${ }^{\text {e }}$ Number of insects (2nd instar), when the experiment started, was 50 insects on each genotype

range from 7.47 to $4.11 \mathrm{~g} / 100 \mathrm{~g}$. The lowest genistein concentrations $(\leq 3.51 \mathrm{~g} / 100 \mathrm{~g})$ were recorded in the L1-1-01, 'Conquista', 'Coodetec 208', and PI 171451 genotypes.
When the control and infested plants were compared, most of the genotypes increased genistein synthesis when exposed to $P$. guildinii. However, an increase in genistein production 


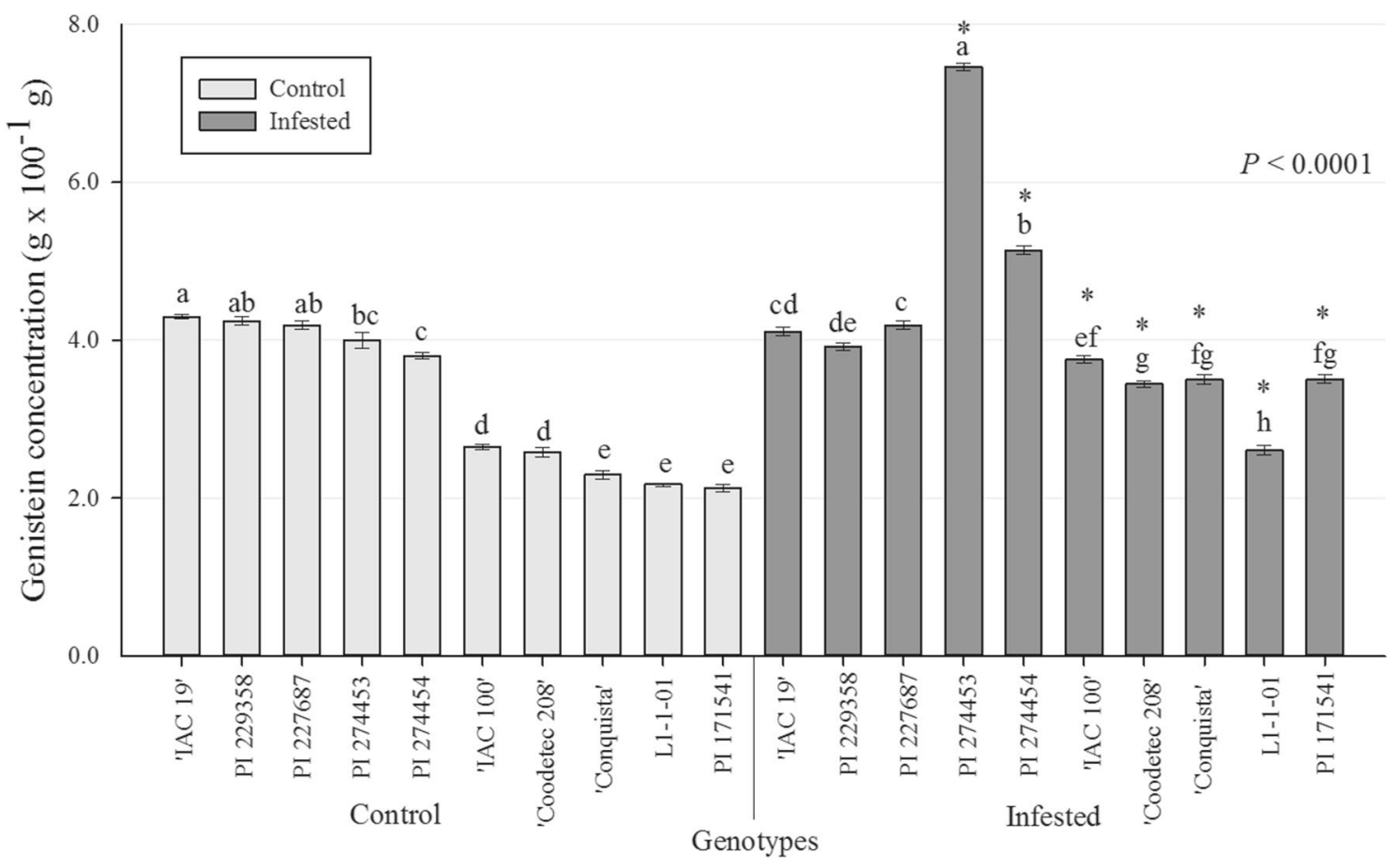

Fig. 2 Mean $\left( \pm\right.$ SE) concentration $\left(\mathrm{g} \times 100^{-1} \mathrm{~g}\right)$ of genistein in ten genotypes for control and infested plants with Piezodorus guildinii. Means followed by the same letter do not differ by the LSD test $(P>0.05)$; Value of $P$ related to the interaction of the two factors

following insect feeding was not observed in 'IAC 19', PI 229358, and PI 227687 genotypes.

Similarly, the highest rutin concentrations $(\geq 19.98 \mathrm{~g} / 100 \mathrm{~g}$ ) were observed in the 'IAC 19', PI 229358, and PI 227687 genotypes (Fig. 3), while the lowest concentrations (ranging from 9.94 to $9.00 \mathrm{~g} / 100 \mathrm{~g}$ ) were observed in the 'Conquista', L1-1-01, and PI 171451 genotypes $(F=174.53 ; \mathrm{df}=19 ; P<0.0001)$. Among the infested plants, the highest rutin concentrations were detected in the PI 274453 and PI 274454 genotypes (37.44 and $25.07 \mathrm{~g} / 100 \mathrm{~g}$, respectively), while the 'Conquista', L1-101 , and PI 171451 genotypes displayed the lowest concentrations of rutin $(<16.32 \mathrm{~g} / 100 \mathrm{~g})$. These genotypes, along with PI 274453, PI 274454, 'IAC 100', and 'Coodetec 208', showed increased rutin concentrations in the infested plants compared with the control plants. Similar to the case for genistein, the 'IAC 19', PI 229358, and PI 227687 genotypes did not increase rutin synthesis following $P$. guildinii infestation.

\section{Discussion}

Although no differences in the total cycle period were noted (2nd instar to adult emergence), the deleterious effects exerted by the 'IAC 100', PI 171451, and L1-1-01 (genotypes and control/infested condition). ${ }^{*}=$ genotypes that exhibit different concentrations of the flavonoid when comparing the control and infested condition

genotypes on nymphal mortality and low emergence suggest antibiosis resistance of these genotypes to $P$. guildinii. The genotypes also impact the nymphal development, prolonging the duration of instars. The results obtained when testing the 'IAC 100', PI 171451, L1-1-01, 'IAC 19', PI 229358, PI 274453, PI 274454, and PI 227687 genotypes indicate antibiosis resistance against $P$. guildinii. A previous study conducted with $P$. guildinii and 17 soybean genotypes also observed antibiosis resistance in the above-mentioned genotypes, although did not evaluated the concentrations of genistein and rutin (Silva et al. 2013). Additionally, studies have shown the expression of antibiosis against the southern green stink bug, Nezara viridula, in the 'IAC 100' and PI 227687 genotypes (Piubelli et al. 2003a, b). Based on previous findings and the present results, identifying secondary compounds in these genotypes is necessary to better understand the mechanism of antibiosis resistance.

Plants are capable of synthesizing a myriad of chemical compounds, such as alkaloids, flavonoids, terpenoids, and sterols, among others (Kubo and Hanke 1986). Flavonoids are widely distributed in plants (Rao et al. 1990, Simmonds 2001), and to play a significant role in host plant resistance, causing deterrence or other deleterious effects in insects (Dixon and Steele 1999). The presence of flavonoids such as rutin and genistein has been reported in some soybean genotypes in previous studies, and their 


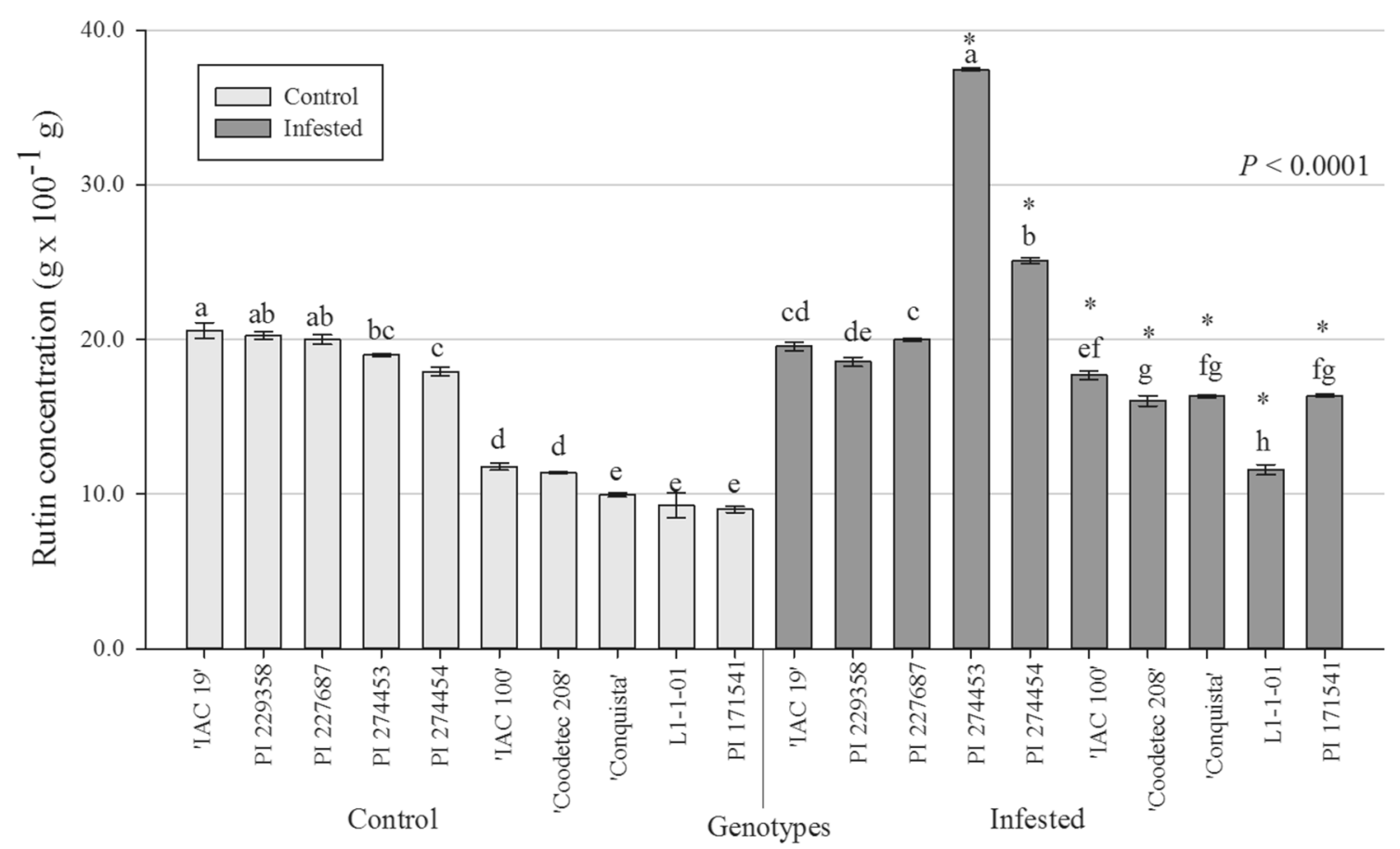

Fig. 3 Mean $( \pm \mathrm{SE})$ concentration $\left(\mathrm{g} \times 100^{-1} \mathrm{~g}\right)$ of rutin in ten genotypes for control and infested plants with Piezodorus guildinii. Means followed by the same letter do not differ by the LSD test $(P>0.05)$; Value of $P$ related to the interaction of the two factors (genotypes and

effects on larval development, survival, pupal weight, and feeding behaviour have been studied in lepidopteran pests, including T. ni (Hoffmann-Campo et al. 2001), A. gemmatalis (Piubelli et al. 2005) and Spodoptera frugiperda (Smith) (Silva et al. 2016), as well as in the orthopteran Schistocerca americana (Drury) (Bernays and Raubenheimer 1991).

Flavonoid effects vary according to insect species (Harborne and Grayer 1993; Smith 2005). The results reported here indicate that the importance of these flavonoids may extend further than lepidopteran insects, playing a significant role against stink bugs such as $P$. guildinii. The identification and further characterization of these important substances in soybean-stink bug interactions might assist future breeding programmes aimed at improving plant defences.

The effects caused by flavonoids in defoliating insects, such as A. gemmatalis and Manduca sexta (Lepidoptera: Sphingidae), appear to be accentuated during instar changes (Stamp 1994; Salvador et al. 2010). In the present study, several nymphs were not able to complete moulting, sometimes dying during this process. The high consumption requirements of these insects before moulting might expose them to high doses of flavonoids, which in turn increases mortality (Salvador et al. 2010). Previous studies have shown that in $A$. gemmatalis, certain enzymes and hormones mediate flavonoid effects by blocking biochemical pathways and reducing control/infested condition). $*$ = genotypes that exhibit different concentrations of the flavonoid when comparing the control and infested condition

the assimilation of essential substances and nutrient storage (Gazzoni et al. 1997).

The high genistein and rutin concentrations found under control conditions in 'IAC 19', PI 229358, and PI 227687 indicate that these flavonoids might be factors in part responsible for antibiosis observed in these genotypes. In addition, the lack of an increase in genistein or rutin concentrations in these genotypes after $P$. guildinii infestation suggests that resistance was not induced. However, the significantly lower levels of these flavonoids observed in the PI 274453, PI 274454, and 'IAC 100' genotypes in control conditions indicate the induction of resistance, and the concentrations that accumulated in these genotypes might have caused the high nymphal mortality observed for $P$. guildinii.

In plant-insect interactions, genes involved in host plant resistance may be expressed either constitutively or as a result of an induced defence response following insect injury (Underwood and Rausher 2002; Underwood et al. 2002; Kaloshian 2004; Smith and Clement 2012). Induced resistance can be defined as the quantitative or qualitative enhancement of a plant's defence mechanism against pests in response to extrinsic physical or chemical stimuli (Smith and Clement 2012). Recent studies conducted with $N$. viridula and soybean demonstrated the presence of other compounds (phytohormones). Attack by insects induces seed defences, involving by mitogen-active protein kinases, which activates 
ethylene emission and jasmonic acid accumulation, to reduce stink bug preference (Giacometti et al. 2016). Here, the induced or constitutive resistance is characterized by the condition of infested and non-infested plants with $P$. guildinii. Genotypes PI 274453, PI 274454, 'IAC 100', 'Coodetec 208', 'Conquista', L1-1-01, PI 171451 expressed induced resistance by elevating the concentration of genistein and rutin after the injury of $P$. guildinii.

The expression of resistance observed in the 'IAC 19', PI 229358, and PI 227687 genotypes in the present study might be constitutive in relation to the synthesis of genistein and rutin, or to morphological factors or other secondary compounds. The injury to PI 274453, PI 274454, and 'IAC 100' soybean plants by $P$. guildinii probably caused the observed increment in the synthesis of genistein and rutin in these genotypes. High concentrations of rutin have been reported in PI 274454 and 'IAC 100' leaves (Piubelli et al. 2005). Previous research has suggested the role of these flavonoids as compounds that might negatively affect the biology of A. gemmatalis and Trichoplusia ni (Hübner) (HoffmannCampo et al. 2001), N. viridula, and Bemisia tabaci (Genn.) (Hemiptera: Aleyrodidae) (Vieira et al. 2016). Other defence mechanisms involving morphological and other secondary compounds might also be involved in resistance expression against stink bug (Smith 2005, Silva et al. 2014). The potential of 'IAC 100' as a resistant genotype is described in the literature (McPherson et al. 2007; McPherson and Buss 2007). This genotype exhibits multiple resistance due to antibiosis and/or antixenosis expression against defoliators (Hoffmann-Campo et al. 1994; McPherson and Buss 2007), P. guildinii and N. viridula (McPherson et al. 2007, Silva et al. 2012, 2013), and has high levels of tolerance against the stink bug complex (Souza et al. 2015).

Although 'Coodetec 208', 'Conquista', L1-1-01, and PI 171451 showed low flavonoid concentrations under control conditions, these genotypes increased the synthesis of flavonoids when fed on by $P$. guildinii. The pods used for the bioassays in this study came from non-infested plants, which might explain the high percentage of adult emergence on the 'Coodetec 208' and 'Conquista' genotypes. It is also important to note that although these genotypes showed an increase in the synthesis of flavonoids, the genistein and rutin concentrations continued to be lower than those in the other genotypes. Recent studies conducted in field in which soybean genotypes were exposed to stink bug infestations showed that the 'Conquista' and 'Coodetec 208' genotypes did not exhibit resistance to the stink bug complex (Souza et al. 2015), which indicates that these genotypes are susceptible to the insects and that the flavonoid levels in these genotypes may not be sufficient to exert negative effects on the biology of $P$. guildinii.

High mortality rates were observed for nymphs reared on the L1-1-01 and PI 171451 genotypes; however, resistance expression in these genotypes appears to be related to other mechanisms. Previous laboratory and field studies reported resistance associated with the PI 171451 genotype: this genotype was classified as repellent (Silva et al. 2013) and showed low leaf retention, low seed damage, and a high yield, indicating antixenotic resistance (Souza et al. 2015). Thus, the possible resistance of this genotype might be related to volatile compounds or to certain morphological characteristics that could repel or inhibit feeding by stink bugs (Piubelli et al. 2003a, b: Smith 2005) and/or cause high nymphal mortality. Volatiles present in the PI genotype leaves may generate repulsive behaviour towards $T . n i$ and Epilachna varivestis (Mulsant) (Liu et al. 1989). Previous laboratory studies classified L1-1-01 as a neutral genotype towards $P$. guildinii; however, the plants of this genotype present a high trichome density and increased pod hardness (Silva et al. 2013), suggesting that the resistance of this genotype may be mostly related to morphological features.

The results showed that the PI 274453, PI 274454, PI 227687, PI 229358, 'IAC 100', and 'IAC 19' genotypes expressed antibiosis to $P$. guildinii and that the flavonoids rutin and genistein appear to play a relevant role in the resistance of these genotypes to $P$. guildinii. Although the L1-101 and PI 171451 genotypes also showed resistance to $P$. guildinii, other defence mechanisms appear to be involved in the plant-insect interaction. Future studies should be conducted to characterize the importance of these compounds for other stink bug species and/or other hemipteran insects. The identification of the mechanisms of action of these important flavonoids in soybean-stink bug interactions and the analysis of the genotypes cited in this study might assist future breeding programmes aimed at improving plant defence tools.

Acknowledgements The authors are grateful to the Coordination for the Improvement of Higher Education Personnel (CAPES) for funding the study. The authors would like to thank Dr. Thomas E. Hunt (Haskell Agricultural Laboratory, University of Nebraska-Lincoln, Concord, $\mathrm{NE}$ ) for his helpful comments and suggestions in the English grammar.

Funding This study was funded by the Coordination for the Improvement of Higher Education Personnel (CAPES).

\section{Compliance with ethical standards}

Conflict of Interest The authors declare that they have no conflict of interest.

\section{References}

Awad AM, Jager AD, Westing LMV (2000) Flavonoid and chlorogenic acid levels in apple fruit: characterization of variation. Sci Hort 83:249-263. https://doi.org/10.1016/S0304-4238(99)00124-7 
Baur ME, Sosa-Gomez DR, Ottea J, Leonard BR, Corso IC, Da Silva JJ, Temple J, Boethel DJ (2010) Susceptibility to insecticides used for control of Piezodorus guildinii (Heteroptera: Pentatomidae) in the United States and Brazil. J Econ Entomol 103:869-879. https://doi.org/10.1603/EC09364

Beggs CJ, Wellmann E (1994) Photocontrol of flavonoid biosynthesis. In: Kendrick RE, Kronenberg GHM (eds) Photomorphogenesis in plants. Kluwer Academic, Dordrecht, pp 733-750

Bernays EA, Raubenheimer D (1991) Dietary mixing in grasshoppers: changes in acceptability of different plant secondary compounds associated with low levels of dietary protein (Orthoptera: Acrididae). J Insect Behav 5:545-556. https://doi.org/10.1007/ BF01048069

Carrão-Panizzi MC, Kitamura K (1995) Isoflavone content in Brazilian soybean cultivars. Japanese J Breed 45(3):295-300

Corrêa-Ferreira BS, Azevedo J (2002) Soybean seed damage by different species of stink bugs. Agric For Entomol 4:145-150. https:// doi.org/10.1046/j.1461-9563.2002.00136.x

Dixon RA, Steele CL (1999) Flavonoids and isoflavonoids-a gold mine for metabolic engineering. Trends Plant Sci 4:394-400

Fehr WR, Caviness CE (1977) Stages of soybean development. Iowa State University, Ames

Gazzoni DL, Hülsmeyer A, Hoffmann-Campo CB (1997) Efeito de diferentes doses de rutina e de quercetina na biologia de Anticarsia gemmatalis Hübner, 1818 (Lepidoptera: Noctuidae). Pesqu Agropecu Bras 32:673-681.

Giacometti R, Barneto J, Barriga LG, Sardoy PM, Balestrasse K, Andrade AM, Pagano EA, Alemano SG, Zavala JA (2016) Early perception of stink bug damage in developing seeds of field-grown soybean induces chemical defences and reduces bug attack. Pest Manag Scie 72:1585-1594. https://doi.org/10.1002/ps.4192

Harborne JB, Grayer RJ (1993) Flavonoids and insects. In: J. B. Harborne (ed) The Flavonoids: advances in research since 1986. London, UK, pp 589-618

Hesler LS, Dashiell KE (2008) Identification and characterization of new sources of resistance to Aphis glycines Matsumura (Hemiptera: Aphididae) in soybean lines. Appl Entomol Zool 43:197206. https://doi.org/10.1303/aez.2008.197

Hoffmann-Campo CB, Mazzarin RM, Lustosa PR (1994) Mecanismos de resistência de genótipos de soja: teste de não-preferência para Anticarsia gemmatalis Hübner, 1818 (lepidoptera: noctuidae). Pesqu. Agropecu. Bras. 29(4):513-519

Hoffmann-Campo CB, Harborne JB, McCaffery AR (2001) Pre-ingestive and post-ingestive effects of soya bean extracts and rutin on Trichoplusia ni growth. Entomol Exp Appl 98:181-194. https:// doi.org/10.1046/j.1570-7458.2001.00773.x

Hulburt DJ, Boerma HR, John N (2004) Effect of pubescence tip on soybean resistance to lepidopteran insects. J Econ Entomol 97:621-627. https://doi.org/10.1603/0022-0493-97.2.621

Kaloshian I (2004) Gene-for-gene disease resistance: bridging insect pest and pathogen defence. J Chem Ecol 30:2421-2439. https:// doi.org/10.1007/s10886-004-7943-1

Kamminga KL, Davis JA, Stock SP, Richter AR (2012) First Report of a mermithid nematode infecting Piezodorus guildinii and Acrosternum hilare (Hemiptera: Pentatomidae) in the United States. Fla Entomol 95:214-217. https://doi.org/10.1653/024.095.0137

Kubo I, Hanke FG (1986) Chemical methods for isolating and identifying phytochemicals biologically active in insects. In: Miller, J. R., and T. A. Miller (eds). Insects-plant interactions. Springer, New York, pp 121-153

Liu SH, Norris DM, Lyne P (1989) Volatiles from the foliage of soybean, Glycine max, and lima bean, Phaseolus lunatus: their behavioral effects on the insects Trichoplusia ni and Epilachna varivestis. J Agric Food Chem 37:496-501. https://doi.org/10.1021/ jf00086a050
Lockwood JA, Story RN (1986) Adaptative functions of nymphal aggregation in the southern green stink bug, Nezara viridula (L.) (Hemiptera: Pentatomidae). Environ Entomol 15:739-749. https:// doi.org/10.1093/ee/15.3.739

Lourenção AL, Reco PC, Baga NR, do Valle GE, Pinheiro JB (2010) Produtividade de genótipos de soja sob infestação da lagarta-dasoja e de percevejos. Neotrop Entomol 39:275-281

Lourencção AL, Miranda MAC, Nagai V (1987) Resistência de soja a insetos: VII. Avaliação de danos de percevejos em cultivares e linhagens. Bragantia 46:45-57. https://doi.org/10.1590/ S0006-87051987000100006

Mazza CA, Zavala J, Scopel AL, Ballaré CL (1999) Perception of solar UVB radiation by phytophagous insects: behavioral responses and ecosystem implications. Proc Natl Acad Sci 96:980-985. https:// doi.org/10.1073/pnas.96.3.980

McPherson RM, Buss GR (2007) Evaluating lepidopteran defoliation resistance in soybean breeding lines containing the stink bug (Hemiptera: Pentatomidae) resistance IAC 100 cultivar in their pedigrees. J Econ Entomol 100:962-968. https://doi. org/10.1603/0022-0493(2007)100[962:ELDRIS]2.0

McPherson JE, McPherson RM (2000) Piezodorus guildinii (Westwood). In: McPherson JE, McPherson RM (eds) Stink bugs of economic importance in America North of Mexico. CRC Press, Florida, USA, pp 177-179

McPherson RM, Douce GK, Hudson RD (1993) Annual variation in stink bug (Heteroptera: Pentatomidae) seasonal abundance and species composition in Georgia soybean and its impact on yield and quality. J Entomol Sci 28:61-72

McPherson RM, Buss GR, Roberts PM (2007) Assessing stink bug resistance in soybean breeding lines containing genes from germplasm IAC 100. J Econ Entomol 100:1456-1463. https:// doi.org/10.1603/0022-0493(2007)100[1456:ASBRIS]2.0.CO;2

Miranda MAC, Rossetto CJ, Rossetto D, Braga NR, Mascarenhas HAA, Teixeira JPF, Massariol A (1979) Resistência de soja a Nezara viridula e Piezodorus guildinii em condições de campo. Bragantia 38:181-188. https://doi.org/10.1590/S0006-87051979000100019

Molina GAR, Trumper EV (2012) Selection of soybean pods by the stink bugs, Nezara viridula and Piezodorus guildinii. J Insect Sci 12:1-16. https://doi.org/10.1673/031.012.10401

Oliveira EDM, Panizzi AR (2003) Performance of nymphs and adults of Piezodorus guildinii (Westwood) (Heteroptera: Pentatomidae) on soybean pods at different development stages. Brazilian Arch Biol Technol 46:187-192. https://doi.org/10.1590/ S1516-89132003000200008

Painter RH (1951) Insect resistance in crop plants. MacMillan, New York

Panda N, Khush GS (1995) Host plant resistance to insects. CAB International, Wallingford

Panizzi AR (1991) Ecologia nutricional de insetos sugadores de sementes. In: Panizzi AR, Parra JRP (eds) Ecologia nutricional de insetos e suas implicações no manejo de pragas. Manole, Brasília, pp 253-287

Panizzi AR, Silva FAC (2009) Insetos sugadores de sementes (Heteroptera). In: Panizzi AR, Parra JRP (eds) Bioecologia e nutricão de insetos. Embrapa, Brasília, pp 465-522

Panizzi AR, Slansky F Jr (1985) Review of phytophagous pentatomids (Hemiptera: pentatomidae) associated with soybean in the Americas. Fla Entomol 68:184-203. https://doi.org/10.2307/3494344

Piubelli GC, Hoffmann-Campo CB, Arruda IC, Lara FM (2003a) Nymphal development, lipid content, growth and weight gain of Nezara viridula (L.) (Heteroptera: pentatomidae) fed on soybean genotypes. Neotrop Entomol 32:127-132. https://doi.org/10.1590/ S1519566X2003000100019

Piubelli GC, Hoffmann-Campo CB, Arruda IC, Franchini JC, Lara FM (2003b) Flavonoid increase in soybean as a response to Nezara 
viridula injury and its effecton insect-feeding preference. J Chem Ecol 29:1221-1233. https://doi.org/10.1023/A:1023889825129

Piubelli GC, Hoffmann-Campo CB, Moscardi F, Miyakubo SH, de Oliveira MC (2005) Are chemical compounds important for soybean resistance to Anticarsia gemmatalis? J Chem Ecol 31:15091524. https://doi.org/10.1007/s10886-005-5794-z

Raij B, Cantarella H, Quaggio J (1997) Recomendações de adubação e calagem para o Estado de São Paulo. Fundação IAC, Campinas

Rao KV, Chattopadhyay SK, Reddy GC (1990) Flavonoids with mosquito larval toxicity. J Agric Food Chem 38:1427-1430. https:// doi.org/10.1021/jf00096a028

Salvador MC, Boiça Júnior AL, Oliveira MCN, Graça JP, Silva DM, Hoffmann-Campo CB (2010) Do different casein concentrations increase the adverse effect of rutin on the biology of Anticarsia gemmatalis Hübner (Lepidoptera: Noctuidae)? Neotrop Entomol 39:774-783. https://doi.org/10.1590/S1519-566X2010000500017

Santos MD, Blatt CTT (1998) Teor de flavonóides e fenóis totais em folhas de Pyrostegia Venusta Miers. de Mata e de Cerrado. Braz J Bot 21:135-140. https://doi.org/10.1590/ S0100-84041998000200004

Sas Software (2001) SAS/STAT: user's guide, version 8.1. SAS Institute, Cary

Silva JPGF, Baldin ELL, Souza ES, Lourenção AL (2012) Assessing Bemisia tabaci (genn.) biotype B resistance in soybean genotypes: antixenosis and antibiosis. Chil. J. Agric. Res. 72(4):516-522

Silva JPGF, Baldin ELL, Souza ES, Canassa VF, Lourenção AL (2013) Characterization of antibiosis to the redbanded stink bug Piezodorus guildinii (Hemiptera: Pentatomidae) in soybean entries. J Pest Sci 86:649-657. https://doi.org/10.1007/s10340-013-0527-5

Silva JPGF, Baldin ELL, Canassa VF, Souza ES, Lourenção AL (2014) Assessing antixenosis of soybean entries against Piezodorus guildinii (Hemiptera: Pentatomidae). Arthropod Plant Interact 8:849859. https://doi.org/10.1007/s11829-014-9316-1

Silva TRFD, Almeira ACS, Moura TL, Silva AR, Freitas SS, Jesus FG (2016) Effect of the flavonoid rutin on the biology of Spodoptera frugiperda (Lepidoptera: noctuidae). Acta Sci 38:165-170. https://doi.org/10.4025/actasciagron.v38i2.27956

Simmonds MSJ (2001) Importance of flavonoids in insect-plant interactions: feeding and oviposition. Phytochemistry 56:245-252. https://doi.org/10.1016/S0031-9422(00)00453-2

Smith CM (2005) Plant resistance to arthropods molecular and conventional approaches. Springer, Dordrecht

Smith C, Clement SL (2012) Molecular Bases of plant resistance to arthropods. Annu Rev Entomol 57:309-328. https://doi. org/10.1146/annurev-ento-120710-100642

Sosa-Gómez DR, Moscardi F (1995) Retenção foliar diferencial em soja provocada por percevejos (Heteroptera: Pentatomidae). An Soc Entomol Brazil 24:401-404

Souza ES, Baldin ELL, Silva JPGF, Lourenção AL (2013) Feeding preference of Nezara viridula (Hemiptera: Pentatomidae) and attractiveness of soybean genotypes. Chil J Agric Res 73:351357. https://doi.org/10.4067/S0718-58392013000400004

Souza ES, Silva JPGF, Baldin ELL, Pierozzi CG, Cunha LS, Canassa VF, Pannuti LER, Lourenção AL (2015) Response of soybean genotypes challenged by a stink bug complex (Hemiptera: Pentatomidae). J Econ Entomol 109:898-906. https://doi.org/10.1093/ jee/tov341
Stamp NE (1994) Simultaneous effects of potassium, rutin and temperature on performance of Manduca sexta caterpillars. Entomol Exp Appl 72:135-143. https://doi.org/10.1111/j.1570-7458.1994. tb01811.x

Sullivan TJ, Rodstrom J, Vandop J, Librizzi J, Graham C, Schardl CL, Bultman TL (2007) Symbiont-mediated changes in Lolium arundinaceum inducible defenses: evidence from changes in gene expression and leaf composition. New Phytol 176:673-679. https://doi.org/10.1111/j.1469-8137.2007.02201.x

Temple JH, Davis J, Micinski S, Hardke JT, Price P, Leonard BR (2013) Species composition and seasonal abundance of stink bugs (Hemiptera: Pentatomidae) in Louisiana soybean. Environ Entomol 42:648-657. https://doi.org/10.1603/EN11135

Todd JW, Turnipseed SG (1974) Effects of southern green stink bug damage on yield and quality of soybeans. J Econ Entomol 67:421426. https://doi.org/10.1093/jee/67.3.421

Underwood N, Rausher M (2002) Comparing the consequences of induced and constitutive plant resistance for herbivore population dynamics. Am Nat 160:20-30. https://doi.org/10.1086/340602

Underwood NC, Rausher M, Cook W (2002) Bioassay versus chemical assay: measuring the impact of induced and constitutive resistance on herbivores in the field. Oecol 131:211-219. https://doi. org/10.1007/s00442-002-0867-y

Valle GE, Lourenção AL (2002) Resistência de genótipos de soja a Bemisia tabaci (Genn.) biótipo B (Hemiptera: Aleyrodidae). Neotrop Entomol 31:285-295. https://doi.org/10.1590/ S1519-566X2002000200017

Vieira SS, Lourenção AL, Graça JP, Janegitz T, Salvador MC, Oliveira MCN, Hoffmann-Campo CB. Biological aspects of Bemisia tabaci biotype $\mathrm{B}$ and the chemical causes of resistance in soybean genotypes. Arthropod Plant Interact 10(6): 525-534.

Webster JA (1975) Association of plant hairs and insect resistance: An annotated bibliography. Agricultural Research Service US Department of Agriculture, washington, D.C

Winer BJ, Brown DR, Michels KM (1991) Statistical principles in experimental design. MacGraw-Hill, New York

Zavala JA, Scopel AL, Ballaré CL (2001) Effects of ambient UV-B radiation on soybean crops: impact on leaf herbivory by Anticarsia gemmatalis. Plant Ecol 156:121-130. https://doi.org/10.102 3/A:1012672226811

Zavala JA, Casteel CL, DeLucia EH, Berenbaum MR (2008) Anthropogenic increase in carbon dioxide compromises plant defense against invasive insects. P Natl Acad Sci USA 105:5129-5133. https://doi.org/10.1073/pnas.0800568105

Zavala JA, Casteel CL, Nabity PD, Berenbaum MR, DeLucia EH (2009) Role of cysteine proteinase inhibitors in preference of Japanese beetles (Popillia japonica) for soybean (Glycine max) leaves of different ages and grown under elevated $\mathrm{CO}_{2}$. Oecol 161:35-41. https://doi.org/10.1007/s00442-009-1360-7

Zavala JA, Mazza CA, Dillon FM, Chludil HD, Ballaré CL (2015) Soybean resistance to stink bugs (Nezara viridula and Piezodorus guildinii) increases with exposure to solar UV-B radiation and correlates with isoflavonoid content in pods under field conditions. Plant, Cell Environ 38:920-928. https://doi.org/10.1111/ pce. 12368

Zerbino MS (2010) Manejo de chinches en soja. Revista INIA 23:24-27 